Pavlenko, A., Hepford, E., \& S. Jarvis (2019) An illusion of understanding: How native and non-native speakers of English understand (and misunderstand) their Miranda rights. The International Journal of Speech, Language and the Law, 26, 2.

\title{
An illusion of understanding: How native and non-native speakers of English understand (and misunderstand) their Miranda rights
}

\author{
Pavlenko, Aneta (University of Oslo), Elizabeth Hepford (Wesleyan University), \\ and Scott Jarvis (University of Utah) ${ }^{1}$
}

In 1966, the Supreme Court of the United States, headed by Chief Justice Earl Warren, made a landmark decision in the case of Miranda $v$. Arizona:

The person in custody must, prior to interrogation, be clearly informed that he has the right to remain silent, and that anything he says will be used against him in court; he must be clearly informed that he has the right to consult with a lawyer and to have a lawyer with him during interrogation, and that, if he is indigent, a lawyer will be appointed to represent him. (Miranda v. Arizona, 1966: 437)

Extending the Fifth Amendment privilege against self-incrimination from the courtroom to the police station, the Miranda decision aimed to safeguard suspects and the court against false and coerced confessions, obtained through deception, physical abuse, threats of punishment, deprivation of basic needs, and prolonged and exhausting interrogations. Once informed of their rights, suspects may relinquish them, "provided the waiver is made voluntarily, knowingly, and intelligently" (Miranda v. Arizona, 1966: 444), that is "with a full awareness of both the nature of the right being abandoned and the consequences of the decision to abandon it" (Colorado $v$. Spring, 1986: 573). If the defense can prove that the defendant waived their rights unknowingly, unintelligently, or involuntarily, their inculpatory statements may be deemed inadmissible, thus weakening the basis for the conviction.

Judges, however, tend to be skeptical of the claims that this or that defendant did not understand their rights. So do many journalists, firmly convinced that, thanks to ubiquitous police and court dramas, even the most casual TV viewers are conversant with their rights: "Anyone who's ever watched "Law \& Order" has a pretty good understanding of Miranda

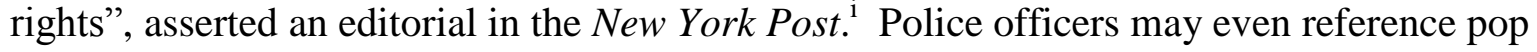
culture before reciting the rights: "Okay, basically and you've heard the Miranda warning on Cops and TV and stuff' (Feld, 2006: 76). Chief Justice William Rehnquist summarized this view succinctly in Dickerson v. United States: "Miranda has become embedded in routine police practice to the point where the warnings have become part of our national culture" (2000: 443). And if they are indeed part of our national culture, who, if anyone, does not understand the warnings and the rights they are intended to convey?

\footnotetext{
${ }^{1}$ For their invaluable contributions to this study, we wish to thank students in Dr. Pavlenko's Forensic Linguistics class Daniel Benenson, Rachel Harr, Valeri Harteg, Gretchen Spencer, Paul Salvitti, and Christina Tavella, who helped design and pilot the data collection instruments; Jacqueline McCafferty, Sheri Mihalovic and Jeremy Samsoe at the Intensive English Language Program at Temple University who facilitated the bulk of the data collection; all of the teachers who welcomed us to their classrooms; the 256 students who volunteered as research subjects for the study; and the former Arizona state trooper James L. Poe for providing us with a recording of a professionally delivered Miranda warning. This study would not have been possible without their generous assistance.
} 


\section{Why native speakers of English do not always understand their rights}

Experts concur that $80 \%$ of adult and $90 \%$ of juvenile custodial suspects customarily waive their rights and talk to the police without a lawyer present (Domanico, Cicchini \& White, 2012; Feld, 2006, 2013; Kassin et al., 2007; Wrightsman \& Pitman, 2010). These strikingly high waiver rates reveal a flaw in the reasoning of the Warren Court: the justices assumed that all suspects possess the intellectual abilities to comprehend their rights and make rational decisions. This assumption was first challenged by Grisso (1981), who found that only $21 \%$ of juvenile and $42 \%$ of adult offenders fully understood their rights. Later research corroborated these findings and established that: (a) knowledge of the Miranda rights among the general population is limited and fraught with misconceptions; (b) comprehension of the Miranda warnings is influenced by the wording and by the listeners'/readers' age, verbal abilities, and levels of education; (c) waiver decisions are affected by trivialization tactics used by the police to circumvent the Miranda (e.g., by presenting it as a simple bureaucratic procedure), as well as by fear, intimidation, or a persistent belief that invocation signals guilt, and (d) some suspects are simply unable to claim their rights effectively (Ainsworth, 2008, 2010; Feld, 2006, 2013; Kassin et al., 2007; Leo, 2008; Rogers et al., 2013; Rogers \& Drogin, 2015; Scherr \& Madon, 2013). The problem with the Miranda rights, observes Ainsworth (2010: 122), is that they "are dangerously easy to waive and nearly impossible to invoke successfully".

Given that $70 \%$ of adult inmates function at or below a $6^{\text {th }}$ grade reading level, it is not surprising that they understand only the simplest sentences (Rogers et al., 2007a, b). Nor do they benefit from prior encounters with the police: detainees perform no better than members of the general population on Miranda comprehension instruments (Roger et al., 2010) and 'frequent flyers' (> 40 arrests) fare no better than those with brief criminal histories ( $<5$ arrests) (Rogers $\&$ Drogin, 2015). When it comes to decision-making, practice does not make perfect either: a study with 80 pretrial detainees revealed that $48.7 \%$ did not consider the long-term consequences of waiving their Miranda rights and 43.8\% could not generate a single long-term reason for exercising their rights (Blackwood et al., 2015). Similar findings come from English-speaking settings outside the US: in Canada, adult offenders understood only $30 \%$ of police cautions (Chaulk, Eastwood \& Snook, 2014), and in the UK, 97\% of detainees claimed to understand, but very few could demonstrate comprehension (Fenner, Gudjonsson \& Clare, 2002; Rock, 2007).

The problems are even greater among vulnerable populations: juveniles and people with mental health problems, cognitive deficits, developmental disabilities, and IQ scores below 75 (Goldstein \& Goldstein, 2010). Research to date compellingly shows that vulnerable persons fail to understand the Miranda warnings due to limitations in language skills, memory capacity, attention span, and information-processing abilities, and are easily manipulated by investigators who take advantage of their high suggestibility, eagerness to comply and please, inability to tolerate high stress, poor impulse control, and privileging of short-term benefits (e.g., food, coffee) over long-term consequences (e.g., felony conviction) (Cloud et al., 2002; Cooper \& Zapf, 2008; Grisso, 1981; Leo, 2008; Rogers et al., 2007b). For some people, argue Cloud and associates (2002: 499), "the words of the warnings literally have no useful meaning".

Psychologists have long been concerned with the rights of vulnerable populations and have developed procedures and standardized instruments to evaluate the competency of the defendants to waive their Miranda rights knowingly (i.e. with an understanding of the rights waived) and intelligently (i.e. with an awareness of the consequences of the waiver) (Atkins \& Weiss, 2011; Goldstein, Zelle \& Grisso, 2012; Grisso, 1998; Rogers et al., 2012). One 
population, however, remains nearly invisible in the research to date - non-native speakers of English.

\section{Why non-native speakers of English may not understand their rights}

In a curious twist of history, the Miranda decision came on the heels of the Immigration and Nationality Act of 1965 that removed the national origins quotas, which had constrained immigration for forty years, and transformed US demographics in ways the Warren Court could not foresee. Whereas in 19709.6 million immigrants constituted 4.7\% of the population, by 2017 the proportion of immigrants almost tripled (13.5\%) and the number more than quadrupled (43.7 million). Today, one in five US residents speaks a language other than English at home (21.8\% of the population; 66.6 million people) and 25.9 million people (9\% of the population) see their English proficiency as limited, among them $55.7 \%$ of Chinese speakers (US Census Bureau, 2018).

In the past decade, a few psychologists and legal experts have acknowledged that speakers with limited English proficiency (LEP) and second language (L2) users in general constitute a vulnerable population when it comes to understanding the Miranda warnings (e.g., Einesman, 2010), others have mentioned it in passing (e.g., Wrightsman \& Pitman, 2010), and yet others have failed to recognize it at all (e.g., Leo, 2008). The Miranda assessment manual by Goldstein and Goldstein (2010: 118) mentions L2 speakers but with no normative data and, in their own research, the authors excluded participants 'unable to speak English fluently' (e.g., Goldstein et al, 2011: 430). To date, only two empirical studies have considered how L2 speakers understand their rights and make relevant decisions. In New Zealand, Innes and Erlam (2018) found that first language (L1) English speakers performed significantly better (90\% to $74 \%$ accuracy) than L2 speakers (61\% to 58\%) on comprehension questions that followed a presentation of the Bill of Rights. In the US, Rogers and associates (2007b) found that L2 English predicted decreased ability to generate reasons for exercising rights among detainees.

The primary reason for the near-invisibility of L2 speakers in Miranda research is a prevailing assumption that they are well-served by existing procedures: those who cannot communicate in English get an interpreter and those who can communicate should understand the warnings. The problem with the first contention is that it has no basis in law. While the Court Interpreters Act of 1978 mandates the provision of an interpreter in court, there is no equivalent law for investigative interviews. In many states, the right to an interpreter does not extend to custodial interrogations, and when interpreters are provided, the growing trend is to use police officers and other ad hoc interpreters. This practice is not against the law but the reliance on police officers does raise the likelihood of coercion and places suspects at the mercy of people whose only qualification may be intermediate Spanish or 'survival skills Russian.' Research shows that officers serving as interpreters still see themselves primarily as interrogators and may perform their add-on duties in a faulty and half-hearted way, failing to interpret stretches of talk, distorting the meanings of key terms (e.g., offering the right to remain calado [soaked, drenched, embroidered], rather than callado [silent]), translating derecho [right] as derecha [the right hand side] and ignoring clear invocations of rights, such as No quiero hablar más [I don't want to talk more] (Berk-Seligson, 2009; Einesman, 2010; Rogers et al, 2009). Distortions and omissions also occur in written texts. In a study of 121 Spanish translations of Miranda warnings, Rogers and associates (2009) found that in $70 \%$ of the cases, Spanish warnings provided less 
information and some omitted the key Miranda components, including the right to silence and the right to counsel.

And if those who do not know English are not well served by interpreters, the contention that those who 'speak English' should understand their rights is even more problematic. Forensic linguists have long tried to convey to the legal community that 'speaking English' is not an all or none proposition: people who can converse on a variety of everyday topics still fail to understand sentences with legal jargon and multiple clauses (Berk-Seligson, 2009; Eades, 2010, 2018; Eggington \& Cox, 2013; Pavlenko, 2008; Shuy, 1997) and people who lack familiarity with the US legal system believe they are required to talk to the police (Goldstein \& Goldstein, 2010: 133-134).

More problems stem from fast speech rates used by the police: Domanico and associates (2012) found that the Miranda rights are commonly delivered at a significantly higher speed (268 words per min) than preceding and subsequent stretches of talk (198 words per min). A similar rate of delivery of the right to silence ( 262 words per min) was documented in Canada (Snook, Eastwood \& McDonald, 2010). These rates exceed the upper range of speech easily understood by L1 English speakers (150-200 words) and may overwhelm L2 speakers, who tend to save face by pretending they understand (Innes \& Erlam, 2018). What this means is that some L2 speakers sign the waiver of rights even when they have no idea what it says (Einesman, 2010).

Law enforcement is not always to blame. Many L2 speakers, argue Eggington and Cox (2013), appear more fluent than they really are, thanks to memorized stock phrases that conceal their gaps in understanding, and police officers do not have the expertise to decide whether the suspect is proficient enough to understand the warnings in English. Neither are forensic psychologists, whose instruments are not normed with L2 speakers of English. The task to determine whether L2 speakers have waived their rights knowingly and intelligently commonly falls to forensic linguists, who evaluate language proficiency using conventional L2 assessment tools (Eggington \& Cox, 2013; English, 2010). The problem with such assessments is that, despite the veneer of objectivity, their validity and reliability are highly questionable when it comes to comprehension of the Miranda rights.

All evaluations of Miranda competency are by definition retrospective and speculative. Nevertheless, Miranda Rights Comprehension Instruments (MRCI), developed by Grisso (1998) and later revised (Goldstein et al., 2012), have gained acceptance in the scientific and legal communities (Atkins \& Weiss, 2011), bolstered by the fact that linguistic and cognitive capacities of L1 English speakers change little during detention: juveniles are still juvenile and people with cognitive disorders and mental illnesses still experience problems with decisionmaking and information-processing. L2 speakers, on the other hand, undergo a transformation immersion in an English-speaking jail environment improves their language skills.

This improvement undermines the validity of assessments conducted several months after the waiver - the proficiency they reveal is not indicative of the suspects' English during the interrogation (cf. English, 2010: 434). Reliability too may be compromised if defendants, advised by 'well-wishers', decide to fake low proficiency or none at all. These problems are circumvented in analyses that rely on interrogation recordings to analyze proficiency and comprehension but such recordings are not always available. Moreover, the two approaches share a common flaw. While MRCI tools assess Miranda comprehension directly, conclusions drawn from proficiency assessments are based on subjective inferences: no studies to date 
provide forensic linguists with the scientific basis for causal connections between L2 proficiency and understanding of the Miranda rights.

\section{Theoretical framework}

To examine this relationship, we first need to define what we mean by 'language proficiency.' Proficiency guidelines published by the American Council on the Teaching of Foreign Languages (ACTFL, 2012) state that people at the highest - Distinguished - level of L2 proficiency are educated and articulate users of the language who can reflect on global issues and highly abstract concepts, understand texts from many genres, and appreciate their nuance and subtlety. Such descriptors, as Hulstijn $(2011,2015)$ rightly points out, confound proficiency with education and intelligence, for there are many L1 speakers who never attain comparable levels.

Hulstijn's $(2011,2015)$ theoretical framework, adopted in this study, dissociates proficiency from intellectual abilities by distinguishing between basic and higher language cognition and core and peripheral components of proficiency. Basic language cognition (BLC), in this view, involves the core components that all native speakers have in common: implicit knowledge of phonetics, phonology, prosody, and morphology and automatic processing of frequent lexical items and basic syntactic structures. Higher language cognition (HLC) involves peripheral components acquired through education - reading and writing skills, metalinguistic knowledge and the ability to process low-frequency words and complex structures - and it is in this domain that variation among L1 speakers is easily observed. This distinction predicts that educated L2 speakers may outperform L1 speakers with low levels of education on tasks involving HLC and perform more poorly on tasks involving BLC.

This framework allows us to distinguish between two types of linguistic obstacles to the comprehension of the warnings. The first type are HLC processing difficulties, shared by L2 speakers and L1 speakers with limited education, which stem from: (a) high information density; (b) low-frequency words and legal terms (e.g., attorney, waiver); and (c) complex hypotheticals and conditionals with passive and agentless constructions and multiple embedded clauses (e.g., If you cannot afford to hire a lawyer, one will be appointed to represent you before any questioning, if you wish one). The second type are BLC processing difficulties unique to L2 speakers, which stem from (a) the rapid-fire rates at which the rights are commonly delivered (e.g., Domanico et al., 2012) and (b) high-frequency words, including conjunctions (if, when), modals (may, have to), and quantifiers (anything), well-familiar to L1 speakers.

The purpose of the present study was to examine the contributions of both types of processing to the comprehension of the Miranda warnings by speakers of English as L1 and L2. Students were chosen as the target population based on the lead author's experiences with cases involving international students, whose understanding of the Miranda rights was taken for granted by the police. Language proficiency was operationalized in the study in three ways. Data from standardized assessments and subsequent student placement allowed us to recruit participants deemed advanced users of L2 English (Table 1). Performance on the listening comprehension task enabled the analysis of the relationship between listening skills and Miranda comprehension, while self-evaluations of proficiency allowed us to analyze the relationship between self-evaluation and performance. The study was guided by three research questions:

(1) Are advanced L2 English speakers comparable to L1 English speakers in their comprehension of the Miranda rights?

(2) If not, what are the causes of additional problems for L2 English speakers? 
(3) Most importantly, do the two groups differ in how they understand the rights?

\section{Research design}

\section{Participants}

265 students participated in the study, all were volunteers, none were remunerated for their participation. The participants were divided into three groups, based on their $\mathrm{L1}^{\mathrm{ii}}$ :

(1) L1 English speakers ( $\mathrm{n}=82$; 43 females, 39 males; ages 18-34, $M=21.7$ ) were undergraduate $(n=80)$ and graduate $(n=2)$ students recruited from linguistics and education classes at Temple University (Philadelphia, PA) and the University of Utah (Salt Lake City, UT);

(2) L1 Chinese speakers ( $\mathrm{n}=117$; 50 females, 67 males; ages $17-28, \mathrm{M}=20.6$ ) were students from mainland China and Taiwan enrolled in English language programs at three Philadelphia universities: Temple, La Salle and Arcadia;

(3) L1 Arabic speakers ( $\mathrm{n}=66$; 21 females, 45 males; ages $17-36, \mathrm{M}=21.7$ ) were students from Saudi Arabia and Kuwait enrolled in English language programs at three Philadelphia universities: Temple, La Salle and Arcadia.

\section{L2 English proficiency}

All L2 English speakers were recruited from upper-level ESL classes. Since different programs rely on different tests and procedures for student placement, we put together an approximate equivalency chart that translates standardized assessments that guided student placement into two common frameworks: ACTFL proficiency guidelines (ACTFL, 2012) and the Common European Framework (CEFR) (CoE, 2018), which has become a valuable reference point for teachers, test developers, education professionals and policy makers around the world.

Table 1. Approximate Equivalency Chart for ACTFL, CEFR, iBT, IELTS and CaMLA

\begin{tabular}{|l|l|l|l|l|l|}
\hline $\begin{array}{l}\text { ACTFL } \\
\text { proficiency } \\
\text { levels }\end{array}$ & $\begin{array}{l}\text { CEFR proficiency } \\
\text { levels }\end{array}$ & $\begin{array}{l}\text { Internet } \\
\text { Based TOEFL } \\
\text { (iBT) (0-120) }\end{array}$ & $\begin{array}{l}\text { IELTS } \\
\mathbf{( 0 - 9 )}\end{array}$ & $\begin{array}{l}\text { CaMLA } \\
\mathbf{( 0 - 8 0 )}\end{array}$ & $\begin{array}{l}\text { Number of } \\
\text { participants }\end{array}$ \\
\hline & Basic user & & & & \\
\hline Intermediate & A2 & & $<4$ & $0-39$ & $\mathrm{n}=4$ \\
\hline & Independent user & & $4-5$ & $40-52$ & $\mathrm{n}=59$ \\
\hline Advanced Low & B1 & 42 & $5.5-6.5$ & $53-63$ & $\mathrm{n}=110$ \\
\hline Advanced Mid & B2 & 72 & & & \\
\hline & Proficient user & & $7-8$ & $64-80$ & $\mathrm{n}=6$ \\
\hline Advanced High & C1 & 95 & 9 & $>80$ & $\mathrm{n}=4$ \\
\hline Superior & $\mathrm{C} 2$ & $>120$ & $9017)$ & Papageorg \\
\hline
\end{tabular}

Sources: ACTFL (2012), CoE (2018), MELAB (2017), Papageorgiou et al. (2015)

According to the CEFR scales, L2 speakers at the A2 level $(n=4)$ can "answer simple questions and respond to simple statements in an interview" (CoE, 2018: 91) and extract information from spoken announcements, written directions, notices, brochures, instructions, regulations and hazard warnings (CoE, 2018: 56-67). Speakers at B1 level $(n=59)$ can deal "with authorities during a foreign visit" (CoE, 2018: 89), "provide concrete information required in an interview" (CoE, 2018: 91), "find and understand relevant information in... letters, brochures, and short official documents" and "scan longer texts in order to locate desired information" (CoE, 2018: 62). The ACTFL guidelines further claim that people at B1 or Advanced Low level 
"can handle appropriately the essential linguistic challenges presented by a complication or an unexpected turn of events" (ACTFL, 2012: 6).

Participants at B2 or higher level $(\mathrm{n}=120)$ "can carry out an effective, fluent interview" (CoE, 2018: 91), cope with complex negotiations resulting from accidents, damages and undeserved traffic tickets (CoE, 2018: 89), "follow the essentials of lectures, talks and reports... which are propositionally and linguistically complex" (CoE, 2018: 57), "scan quickly through long and complex texts locating relevant details" (CoE, 2018: 62), and "explain a viewpoint on a topical issue giving the advantages and disadvantages of various options" (CoE, 2018: 72). Given this wide range of BLC and HLC abilities, we hypothesized that, regardless of prior familiarity with Miranda, most, if not all, of our participants should be able to understand the warnings and the rights they are intended to convey.

\section{$\underline{\text { Research methods }}$}

Procedure

The data were collected during one-hour long sessions. At the start, the researchers explained that the study examined comprehension of legal language and outlined individual tasks. If the data were collected in class, students were given the option to opt out by working with their instructor on another task. L1 volunteers were given informed consent forms in English and L2 speakers in English and either Arabic or Chinese. Each session involved three tasks: Task 1 Listening Comprehension, Task 2 Miranda Vocabulary Assessment, and Task 3 Miranda Comprehension. Our discussion here will be limited to Tasks 1 and 3.

Table 2. Number of participants per task ${ }^{\text {iii }}$

\begin{tabular}{|l|l|l|l|l|l|l|}
\hline Participants & $\begin{array}{l}\text { Task 1 } \\
\text { Listening }\end{array}$ & $\begin{array}{l}\text { Task 2 } \\
\text { Vocabulary }\end{array}$ & $\begin{array}{l}\text { Task 3a } \\
\text { Recall }\end{array}$ & $\begin{array}{l}\text { Task 3b } \\
\text { Paraphrase }\end{array}$ & $\begin{array}{l}\text { Task 3c } \\
\text { Dictation }\end{array}$ & $\begin{array}{l}\text { Task 3d } \\
\text { Scenarios }\end{array}$ \\
\hline L1 English & $\mathrm{N}=82$ & $\mathrm{~N}=82$ & $\mathrm{~N}=21$ & $\mathrm{~N}=41$ & $\mathrm{NA}$ & $\mathrm{N}=20$ \\
& $\mathrm{~F}=43$ & $\mathrm{~F}=43$ & $\mathrm{~F}=14$ & $\mathrm{~F}=23$ & & $\mathrm{~F}=6$ \\
& $\mathrm{M}=39$ & $\mathrm{M}=39$ & $\mathrm{M}=7$ & $\mathrm{M}=18$ & & $\mathrm{M}=14$ \\
\hline L1 Arabic & $\mathrm{N}=66$ & $\mathrm{~N}=66$ & $\mathrm{~N}=24$ & $\mathrm{~N}=21$ & $\mathrm{NA}$ & $\mathrm{N}=21$ \\
& $\mathrm{~F}=21$ & $\mathrm{~F}=21$ & $\mathrm{~F}=10$ & $\mathrm{~F}=2$ & & $\mathrm{~F}=9$ \\
& $\mathrm{M}=45$ & $\mathrm{M}=45$ & $\mathrm{M}=14$ & $\mathrm{M}=19$ & & $\mathrm{M}=12$ \\
\hline L1 Chinese & $\mathrm{N}=117$ & $\mathrm{~N}=117$ & $\mathrm{~N}=44$ & $\mathrm{~N}=38$ & $\mathrm{~N}=12$ & $\mathrm{~N}=23$ \\
& $\mathrm{~F}=50$ & $\mathrm{~F}=50$ & $\mathrm{~F}=22$ & $\mathrm{~F}=15$ & $\mathrm{~F}=5$ & $\mathrm{~F}=8$ \\
& $\mathrm{M}=67$ & $\mathrm{M}=67$ & $\mathrm{M}=22$ & $\mathrm{M}=23$ & $\mathrm{M}=7$ & $\mathrm{M}=15$ \\
\hline
\end{tabular}

\section{Research instruments}

\section{Task 1 Listening Comprehension}

Task 1 served as a common measure of listening proficiency. The participants were asked to listen to a recording with 20 sentences, one at a time, and to write down exactly what they heard. To disambiguate syntactic and lexical effects, we included four sets of five sentences: (a) short sentences with simple syntax and high-frequency words (e.g., He can run very quickly); (b) long sentences with complex syntax and high-frequency words (e.g., If you do not know the answer, the teacher will help you); (c) short sentences with simple syntax and legal terms (e.g., Jurors decide who is guilty) and (d) long sentences with complex syntax and legal terms (e.g., The prosecutor objected to the use of expert witness's testimony since their methods were not 
falsifiable or generally accepted in the field). Ten sentences were recorded by a male speaker and 10 by a female. To give participants sufficient time, each sentence was followed by a pause based on the number of syllables in the sentence ( $2 \mathrm{sec}$ per syllable).

Participants' responses were entered into an Excel spreadsheet, with spelling errors corrected, and scored by a computer application that converted the original sentences and participants' versions into pairs of words (bigrams) that represented every possible pairing. The binomial coefficients were calculated as $1+2+3+4+\ldots+n$, where $n$ is the number of words in the sentence minus one. More simply, the maximum number of points was calculated as $\mathrm{n}(\mathrm{n}+1) / 2$. Subsequently, we conducted quantitative analyses of the relationship between listening proficiency and performance and of the syntactic and lexical effects on sentence processing.

\section{Task 3 Miranda Comprehension}

In Task 3 participants were randomly assigned to one of four conditions (Table 2). In Task $3 \mathrm{~b}$ Paraphrase, they were asked to listen to recorded Miranda warnings one sentence at a time and write down each sentence in their own words. In the absence of a standard text of the Miranda warning, we selected one that is commonly used in many jurisdictions and studies of comprehension of the Miranda rights (e.g., Berk-Seligson, 2009):

You have the right to remain silent.

Anything you say can and will be used against you in a court of law.

You have the right to talk to a lawyer and to have him present with you while you are being questioned.

If you cannot afford an attorney, one will be appointed to represent you before any questioning if you wish.

You can decide at any time to exercise these rights and not answer any questions or make any statements.

Do you understand each of these rights I have explained to you?

Having these rights in mind, do you wish to talk to us now?

The recording was made by a former state trooper who articulated the warnings at the same pace as he would normally use with suspects -3 words per second or 183 words per min, which was significantly lower than the rates documented by Domanico et al (2012). A pause of two seconds per syllable was inserted after each sentence. Aural presentation format was chosen because police officers report that they are more likely to deliver rights orally (67\%) than in writing (29\%) (Kassin et al., 2007), and a written response format was chosen to evaluate the participants' unassisted ability to paraphrase the warnings. All responses were entered into an Excel spreadsheet and rated by three independent evaluators who scored each clause separately, assigning 0 for blanks or misunderstood clauses, 1 for partial understanding and 2 for full understanding (a total of $22 \mathrm{pts}$ ).

An additional group of $12 \mathrm{~L} 1$ Chinese speakers was assigned Task 3c Dictation, where they listened to the same recording as in Task $3 \mathrm{~b}$, but were asked to write down the sentences exactly as they heard them. The purpose of the task was to examine whether inadequate paraphrases might stem from paraphrasing difficulties. All responses to Task $3 \mathrm{c}$ were entered into an Excel spreadsheet and scored as described above. In both cases, the interrater reliability was high (93\% to 97\%) and discrepancies were discussed until consensus was reached. Next, we calculated mean accuracy rates for each right. The quantitative analysis examined the effects of 
listening proficiency on the comprehension of the warnings, and qualitative analysis identified the key linguistic challenges for the participants.

\section{Results}

\section{RQ1: Comprehension of Miranda warnings by L1 and L2 English speakers}

Aggregated, group-level descriptive statistics for Task 1, Task $3 \mathrm{~b}$ and Task $3 \mathrm{c}$ are shown in Table 3. For ease of inter-group comparison, statistical information for these groups and tasks is also shown graphically in the boxplots in Figures 1-3.

Table 3. Group-level performance across tasks

\begin{tabular}{|l|l|l|l|}
\hline Group & $\begin{array}{l}\text { Task 1 } \\
\text { Listening }\end{array}$ & $\begin{array}{l}\text { Task 3b } \\
\text { Paraphrase }\end{array}$ & $\begin{array}{l}\text { Task 3c } \\
\text { Dictation }\end{array}$ \\
\hline L1 English & $\mathrm{n}=82$ & $\mathrm{n}=41$ & N/A \\
& $\mathrm{m}=.748$ & $\mathrm{~m}=18.80$ & \\
$\mathrm{sd}=.093$ & $\mathrm{sd}=2.33$ & \\
\hline L1 Arabic & $\mathrm{n}=66$ & $\mathrm{n}=21$ & N/A \\
& $\mathrm{m}=.286$ & $\mathrm{~m}=6.86$ & \\
& $\mathrm{sd}=.133$ & $\mathrm{sd}=4.45$ & \\
\hline L1 Chinese & $\mathrm{n}=117$ & $\mathrm{n}=38$ & $\mathrm{n}=12$ \\
& $\mathrm{~m}=.218$ & $\mathrm{~m}=3.24$ & $\mathrm{~m}=4.67$ \\
& $\mathrm{sd}=.091$ & $\mathrm{sd}=3.01$ & $\mathrm{sd}=2.74$ \\
\hline
\end{tabular}

A summary of scores on Task $3 b$ in Figure 1 shows that L1 English speakers were significantly more accurate than L2 speakers, with L1 Arabic speakers achieving higher scores than L1 Chinese speakers. A Kruskal-Wallis test showed a significant difference across all three groups $(\mathrm{H}=74.59, \mathrm{df}=2, \mathrm{p}<.001)$, and post-hoc Mann-Whitney tests indicated that the differences were significant between each pair (English vs. Arabic, $U=8.50, p<.001$; English vs. Chinese, $U=1.00, p<.001$; Arabic vs. Chinese, $U=207.00, p=.002) .{ }^{\text {iv }}$

The overall distribution of the data reveals that a score of 15 is the lower threshold for native-like performance on the Miranda Paraphrase for L1 English speakers who grew up in the US and are pursuing a bachelor's degree. This score, however, represents comprehension of about $68 \%$ of the text. Full comprehension, evident in a score of 22, was achieved by only four L1 English speakers (10\%). Three L1 English speakers had scores below 15, the lower fence for their group (here and further on, the numbers next to each outlier represent case or row numbers in our SPSS datafile). The reasons for such low scores are not clear - the participants may have been distracted or may not have taken the task seriously. 


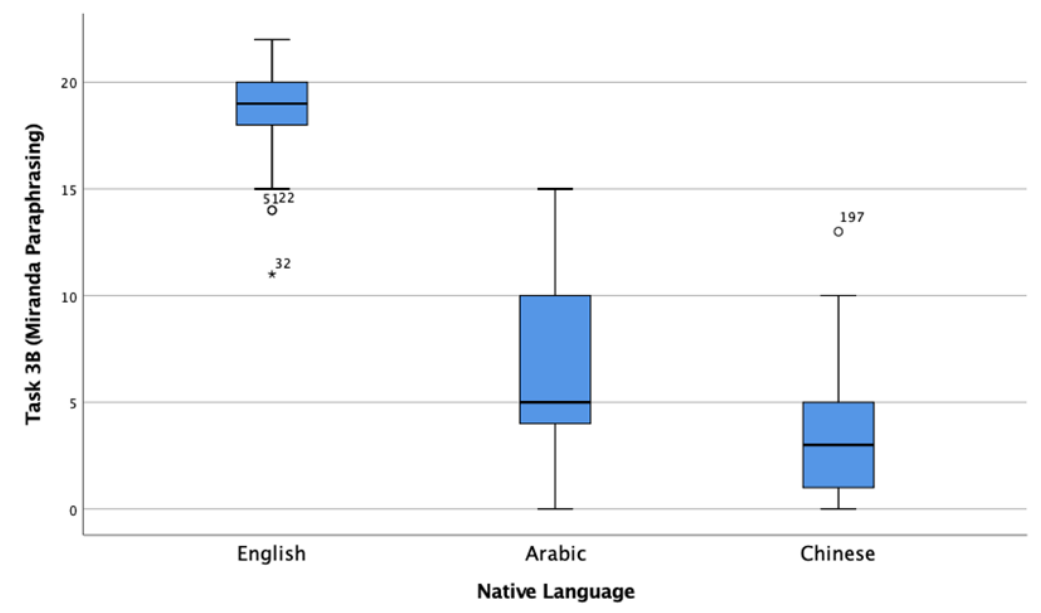

Figure 1. Boxplot for Task 3b Miranda Paraphrase (max possible score $=22$ )

These results do not provide us with an objective means for determining whether a certain score below 22 constitutes an adequate understanding of the Miranda rights, but it is extremely unlikely that anyone who has achieved a score below the threshold of 15 could have understood the warnings. If we adopt a score of 15 as the minimum comprehension threshold, our study demonstrates that no L1 Chinese speakers and only two L1 Arabic speakers reached this threshold, each with a score of only 15. To the extent that these results are generalizable, they suggest that only $3.4 \%$ (i.e., 2/59) of L2 speakers enrolled in advanced-level ESL courses are able to demonstrate even a marginal understanding of the Miranda warnings. In contrast, eight L2 speakers (13.6\%) received a score of 0, demonstrating no comprehension at all.

To explore the possibility that some participants may understand the rights but lack the means to paraphrase them, we assigned a subset of the L1 Chinese group to Task 3c Dictation, where they had to write each individual statement as they heard it. Figure 2 summarizes the scores of the 38 Chinese participants who performed Task $3 \mathrm{~b}$ and the scores of the 12 Chinese participants who completed Task $3 \mathrm{c}$.

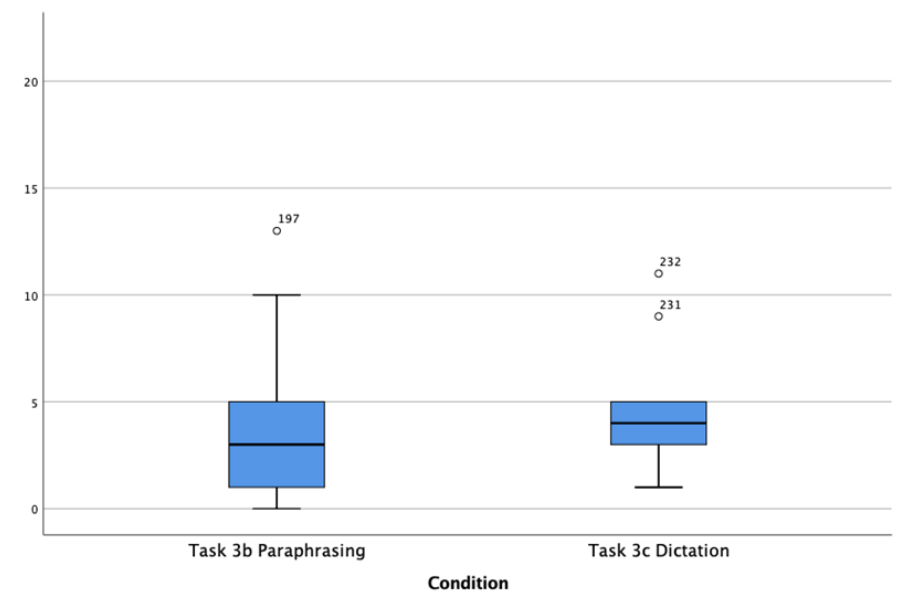

Figure 2. Boxplot for the Chinese group's performance on Tasks $3 \mathrm{~b}$ and $3 \mathrm{c}(\max$ possible $=22)$ 
As one can see, participants in Task 3c have a slightly higher median score but overall the dictation task did not result in higher scores. This was confirmed with a Mann-Whitney test, which showed that the differences between the $3 b$ and $3 c$ scores are not significant $(U=159.50$, $\mathrm{p}=.116)$. Thus, we have no reason to assume that paraphrasing scores underestimate participants' comprehension of the Miranda warnings.

\section{RQ2: Factors affecting comprehension of Miranda warnings by L2 speakers}

Our second research question concerns the causes of L2 speakers' difficulties. To examine the effects of their English proficiency, we converted the participants' CEFR levels, summarized in Table 1 , into numerical values, with $\mathrm{B} 1=3, \mathrm{~B} 2=4, \mathrm{C} 1=5$, and $\mathrm{C} 2=6$. We then ran a Spearman's correlation test on the converted CEFR values vs. the scores on Task $3 b$ Miranda Paraphrase in order to determine the degree to which L2 participants' comprehension co-varied with their levels of English proficiency. The results of the test showed a small and nonsignificant relationship between the two variables $\left(\mathrm{r}_{\mathrm{s}}=.217, \mathrm{n}=59, \mathrm{p}=.099\right)$. We then reran the correlation task, combining the results of Tasks $3 b$ and $3 c$ into a single variable. The results once again showed a nonsignificant relationship between proficiency level and Miranda comprehension $\left(\mathrm{r}_{\mathrm{s}}=.224, \mathrm{n}=71, \mathrm{p}=.061\right)$, revealing that an increase in overall proficiency does not necessarily result in improved comprehension

We next looked at whether the L2 participants' ability to demonstrate a threshold level of Miranda rights comprehension (i.e., a score of 15 or higher) presupposed a minimum level of English proficiency. Table 4 shows the numbers of L2 speakers in each group who demonstrated this criterion level. Earlier, we reported that $3.4 \%$ of the L2 speakers reached a score of 15 on Task $3 b$. Table 4 shows that this value decreases to $2.82 \%(2 / 71)$ when the Task $3 c$ data are included. Given the large sample sizes for levels B1-B2+ we find that the probability of even marginal comprehension of the Miranda rights is close to $0 \%$ for anyone below level $\mathrm{C} 1$.

Table 4. Miranda rights comprehension by proficiency level

\begin{tabular}{|lllll|}
\hline CEFR Level & Arabic speakers & Chinese speakers & TOTAL RAW & TOTAL \% \\
\hline B1 & $0 / 6$ & $0 / 16$ & $0 / 22$ & $0.00 \%$ \\
B1-C1 & $0 / 2$ & $0 / 3$ & $0 / 5$ & $0.00 \%$ \\
B2 & $0 / 3$ & $0 / 0$ & $0 / 3$ & $0.00 \%$ \\
B2+ & $0 / 3$ & $0 / 30$ & $0 / 33$ & $0.00 \%$ \\
C1 & $1 / 6$ & $0 / 0$ & $1 / 6$ & $16.67 \%$ \\
C2 & $1 / 1$ & $0 / 1$ & $1 / 2$ & $50.00 \%$ \\
\hline TOTAL & $2 / 21$ & $0 / 50$ & $2 / 71$ & $2.82 \%$ \\
\hline
\end{tabular}

To look more closely at the nature of the problem we analyzed the results of Task 1 Listening comprehension. As seen in Figure 3, the scores of the L1 English group were normally distributed and substantially higher than those of the L2 speakers who had some outliers at the upper end of their distributions. A Kruskal-Wallis test found a significant difference across all three groups in Task 1 performance $(\mathrm{H}=174.53, \mathrm{df}=2, \mathrm{p}<.001)$, and post-hoc Mann-Whitney tests showed that the differences were significant for each pair (English vs. Arabic, $\mathrm{U}=25.50, \mathrm{p}$ $<.001$; English vs. Chinese, $U=5.00, \mathrm{p}<.001$; Arabic vs. Chinese, $\mathrm{U}=2600.50, \mathrm{p}<.001)$. In other words, the results show that the general listening comprehension scores for L1 English speakers are significantly higher than those of the L1 Arabic and L1 Chinese groups, and that the L1 Arabic group has significantly higher listening comprehension scores than the L1 Chinese 
group. There is nevertheless some overlap in the score distributions of the L1 English and L1 Arabic groups, and a great deal of overlap in the distributions of the L2 groups.

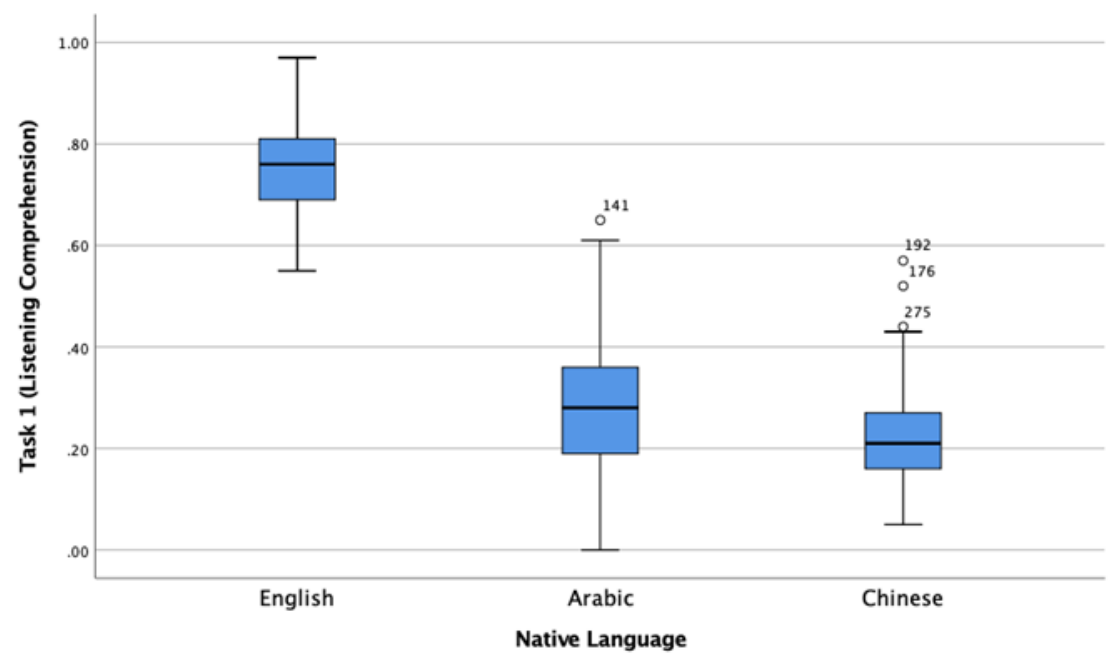

Figure 3. Boxplot for Task 1 Listening Comprehension $(\max$ possible score $=1.00)$

To understand the contribution of lexical and syntactic factors to listening difficulties we then conducted separate analyses of four types of sentences comprised in Task 1. Table 5 shows how the four sets varied in terms of lexical frequency (calculated via textinspector.com using COCA lexical frequency count per type), sentence length (mean words per sentence), and syntactic complexity (calculated as the complex T-unit ratio via the L2 Syntactic Complexity Analyzer; see Lu, 2010) and displays the means and standard deviations for each group.

Table 5. Group listening comprehension performance by sentence type (max score $=1.00$ )

\begin{tabular}{|l|l|l|l|l|l|l|}
\hline Sentence type & $\begin{array}{l}\text { Mean } \\
\text { lexical } \\
\text { frequency }\end{array}$ & $\begin{array}{l}\text { Mean } \\
\text { sentence } \\
\text { length }\end{array}$ & $\begin{array}{l}\text { Mean } \\
\text { syntactic } \\
\text { complexity }\end{array}$ & $\begin{array}{l}\text { L1 English } \\
\text { Task 1 } \\
\text { (n= 82) }\end{array}$ & $\begin{array}{l}\text { L1 Arabic } \\
\text { Task 1 } \\
\text { (n= 66) }\end{array}$ & $\begin{array}{l}\text { L1 Chinese } \\
\text { Task 1 } \\
\text { (n = 117) }\end{array}$ \\
\hline $\begin{array}{l}\text { Set 1: short } \\
\text { sentences, } \\
\text { simple syntax, } \\
\text { high-frequency } \\
\text { words }\end{array}$ & 650.84 & $5.2 \mathrm{wds}$ & 0.000 & $\begin{array}{l}\mathrm{m}=.966 \\
\mathrm{sd}=.053\end{array}$ & $\begin{array}{l}\mathrm{m}=.823 \\
\mathrm{sd}=.163\end{array}$ & $\begin{array}{l}\mathrm{m}=.738 \\
\mathrm{sd}=.190\end{array}$ \\
\hline $\begin{array}{l}\text { Set 2: long } \\
\text { sentences, } \\
\text { complex syntax, } \\
\text { high-frequency } \\
\text { words }\end{array}$ & 725.45 & $15.4 \mathrm{wds}$ & 0.800 & $\begin{array}{l}\mathrm{m}=.907 \\
\mathrm{sd}=.083\end{array}$ & $\begin{array}{l}\mathrm{m}=.432 \\
\mathrm{sd}=.186\end{array}$ & $\begin{array}{l}\mathrm{m}=.330 \\
\mathrm{sd}=.144\end{array}$ \\
\hline $\begin{array}{l}\text { Set 3: short } \\
\text { sentences, } \\
\text { simple syntax, } \\
\text { legal terms }\end{array}$ & 2420.97 & $8.6 \mathrm{wds}$ & 0.200 & $\begin{array}{l}\mathrm{m}=.937 \\
\mathrm{sd}=.089\end{array}$ & $\begin{array}{l}\mathrm{m}=.242 \\
\mathrm{sd}=.202\end{array}$ & $\begin{array}{l}\mathrm{m}=.162 \\
\mathrm{sd}=.110\end{array}$ \\
\hline $\begin{array}{l}\text { Set 4: long } \\
\text { sentences, } \\
\text { complex syntax, } \\
\text { legal terms }\end{array}$ & 3697.14 & $14.2 \mathrm{wds}$ & 0.600 & $\begin{array}{l}\mathrm{m}=.482 \\
\mathrm{sd}=.160\end{array}$ & $\begin{array}{l}\mathrm{m}=.080 \\
\mathrm{sd}=.080\end{array}$ & $\begin{array}{l}\mathrm{m}=.052 \\
\mathrm{sd}=.042\end{array}$ \\
\hline
\end{tabular}


As seen in Figure 4, L1 speakers recalled the sentences in Sets 1-3 with over 90\% accuracy. They did, however, struggle with long complex sentences, containing legal terms (e.g., defendant, precedent, sentencing, expert witness). L2 English speakers performed fairly well on Set 1, as expected from students enrolled in advanced-level ESL courses. They were only about half as accurate in their recall of Set 2 and even less accurate with Set 3 and Set 4 . In fact, the mean accuracy rate for the L2 groups in relation to their ability to recall Set 4 sentences-i.e., the sentences which are qualitatively the most similar to the Miranda warnings-was less than $10 \%$. These results highlight two important findings: (a) even L1 speakers struggle with complex sentences containing legal terms, and (b) L2 speakers' strong performance in processing simple sentences with familiar words is not indicative of their ability to process short sentences with legal terms and belies their substantial inability to process complex sentences with legal jargon.

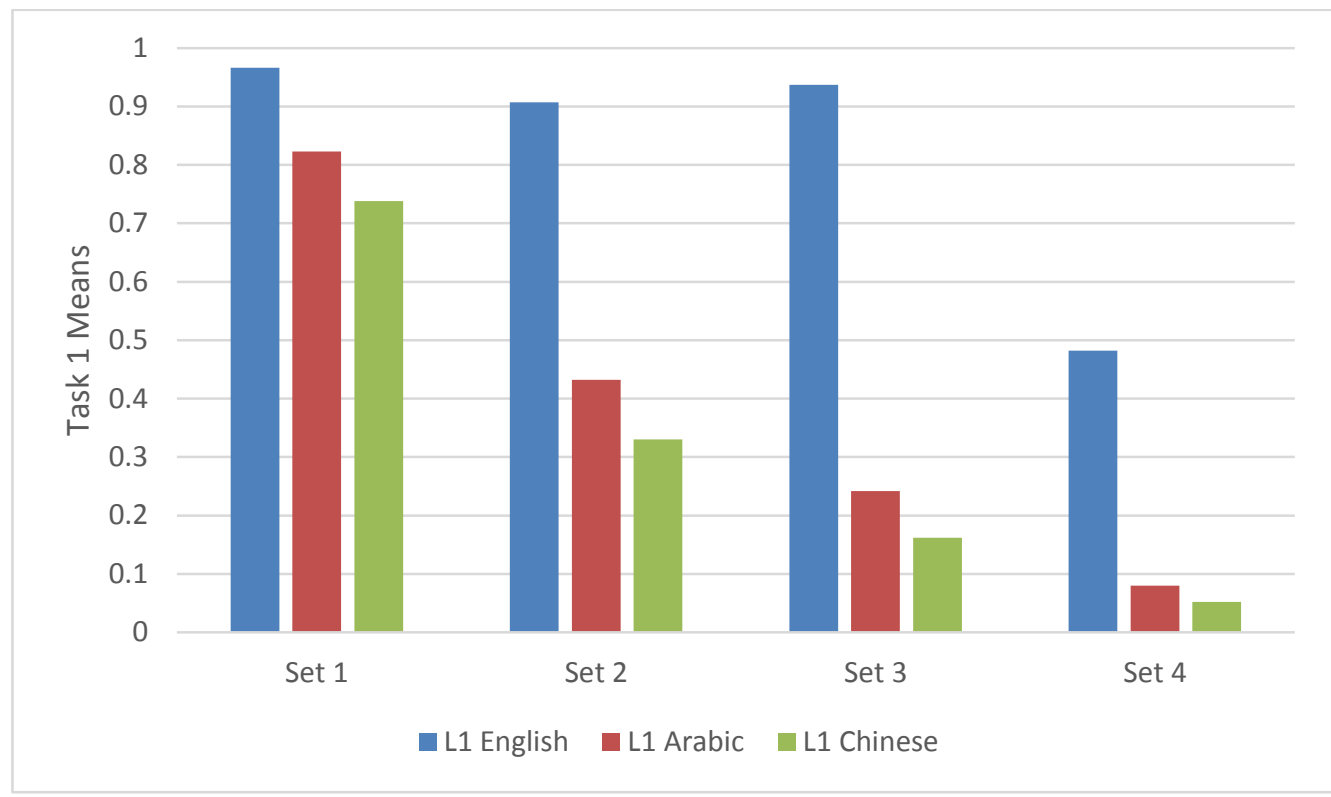

Figure 4. Group listening comprehension performance by sentence type

Strikingly, our L2 participants weren't always conscious of their own challenges. Our qualitative analysis revealed that while some participants left blank spaces in place of legal terms, other participants filled the spaces with the words they inferred or thought they heard. Thus, in the sentence Jurors decide who is guilty, the unfamiliar term jurors was commonly substituted with judge or, alternatively, Joe, Judy, George, or Jews. In turn, the sentence The American legal system depends on the precedents set by previous cases was rendered by several participants as The American legal system depends on the President. These substitutions - based on phonological similarity and approximate semantic fit - remind us that word meanings are not simply 'retrieved' from the bilingual lexicon but actively constructed on-line, with the mind filling the gaps based on preexisting knowledge. Insofar as this is true, did these compensatory strategies affect the L2 speakers' understanding of the Miranda warnings? 
RQ3: Do L1 and L2 speakers differ in how they understand the Miranda rights?

The Miranda warnings presented to our participants included six rights, some of which were easier to comprehend than others. The numbers of participants who displayed at least a partial understanding of each right in Tasks $3 \mathrm{~b}$ and $3 \mathrm{c}$ are shown in Table 6. Our findings show that the right to free access to an attorney before questioning was the most challenging for all. None of the L2 speakers included this right and only $19.5 \%$ of the L1 English speakers did. On the other rights L1 English speakers performed exceedingly well: they were approximately four times more likely than the L2 speakers to understand their fundamental right to silence (95.1\% vs. $25.4 \%$ ), approximately twice as likely to understand that they have the right to an attorney (100\% vs. $53.5 \%)$, and more than 14 times more likely to understand that an attorney can be appointed to them for free ( $97.6 \%$ vs. $7.0 \%)$. As to the L2 speakers, fewer than $10 \%$ of L1 Chinese speakers demonstrated an understanding of four of the six rights and only one right was identified by at least $50 \%$ of the L2 participants in each group - the right to a lawyer.

Table 6. Participants who demonstrated an understanding of each right

\begin{tabular}{|l|l|l|l|l|l|}
\hline Miranda rights & $\begin{array}{l}\text { L1 English } \\
\text { Task 3b } \\
(\mathbf{n = 4 1})\end{array}$ & $\begin{array}{l}\text { L1 Arabic } \\
\text { Task 3b } \\
(\mathbf{n = 2 1})\end{array}$ & $\begin{array}{l}\text { L1 Chinese } \\
\text { Task 3b } \\
(\mathbf{n = 3 8})\end{array}$ & $\begin{array}{l}\text { L1 Chinese } \\
\text { Task 3c } \\
\text { (n= 12) }\end{array}$ & $\begin{array}{l}\text { L1 Chinese } \\
\text { Total } \\
\text { (n=50) }\end{array}$ \\
\hline Right to silence & $39(95.1 \%)$ & $6(28.6 \%)$ & $8(21.0 \%)$ & $4(33.3 \%)$ & $12(24.0 \%)$ \\
\hline Right to a lawyer & $41(100 \%)$ & $14(66.7 \%)$ & $16(42.1 \%)$ & $8(66.7 \%)$ & $24(50.0 \%)$ \\
\hline $\begin{array}{l}\text { Right to have a } \\
\text { lawyer present } \\
\text { during questioning }\end{array}$ & $36(87.8 \%)$ & $5(23.8 \%)$ & $1(2.6 \%)$ & $1(8.3 \%)$ & $2(4.0 \%)$ \\
\hline $\begin{array}{l}\text { Free access to an } \\
\text { attorney }\end{array}$ & $40(97.6 \%)$ & $2(9.5 \%)$ & $2(5.3 \%)$ & $1(8.3 \%)$ & $3(6.0 \%)$ \\
\hline $\begin{array}{l}\text { Free access to an } \\
\text { attorney before } \\
\text { questioning }\end{array}$ & $8(19.5 \%)$ & $0(0 \%)$ & $0(0 \%)$ & $0(0 \%)$ & $0(0 \%)$ \\
\hline $\begin{array}{l}\text { Right to exercise } \\
\text { these rights at any } \\
\text { time }\end{array}$ & $40(97.6 \%)$ & $9(42.9 \%)$ & $3(7.9 \%)$ & $1(8.3 \%)$ & $4(8.0 \%)$ \\
\hline
\end{tabular}

To see whether L1 and L2 speakers differed in how they understood the warnings, we separated blanks and strings of random words and non-words from complete sentences that made sense while deviating from the actual warnings. We found that some L2 speakers compensated for gaps in listening comprehension by reconstructing the sense of what they heard based on the words they understood or thought they did (see examples in Table 7). Unexpectedly, the words that caused the biggest problems were neither legal terms, nor low-frequency words, like afford. The primary source of confusion involved high-frequency English words.

Table 7. L2 speakers' accuracy rates and adequate and inadequate paraphrases

\begin{tabular}{|l|l|l|}
\hline \multicolumn{1}{|c|}{$\begin{array}{c}\text { L2 speakers' } \\
\text { accuracy rates }\end{array}$} & \multicolumn{1}{c|}{ Examples of adequate paraphrases } & \multicolumn{1}{c|}{ Examples of inadequate paraphrases } \\
\hline $\begin{array}{l}\text { You have the right to } \\
\text { remain silent. } \\
(25.3 \%)\end{array}$ & $\begin{array}{l}\text { You don't have to talk with us. } \\
\text { You have the opportunity to say nothing. }\end{array}$ & $\begin{array}{l}\text { You have to stay quiet. } \\
\text { You have to do something (write). } \\
\text { You have to write your own. }\end{array}$ \\
\hline You have the right to & I have the right to talk to my lawyer. & You have the right to talk to a presenter. \\
\hline
\end{tabular}




\begin{tabular}{|c|c|c|}
\hline $\begin{array}{l}\text { talk to a lawyer... } \\
(53.5 \%)\end{array}$ & $\begin{array}{l}\text { Wait for your lawyer if you want when } \\
\text { they ask you. }\end{array}$ & $\begin{array}{l}\text { Have right to do smth such as talk to president. } \\
\text { You can talk to the president. }\end{array}$ \\
\hline $\begin{array}{l}\text {... and to have him } \\
\text { present with you } \\
\text { while you are being } \\
\text { questioned. } \\
(10.0 \%)\end{array}$ & $\begin{array}{l}\text { You get a lawyer for your questioning. } \\
\text { When I ask your question you have right } \\
\text { not to talk until your lawyer come. }\end{array}$ & $\begin{array}{l}\text { It's OK to bring lawyer to court. } \\
\text { Talk to lawyer why you are questioned. } \\
\text { If you have question you can ask your lawyer. }\end{array}$ \\
\hline $\begin{array}{l}\text { If you cannot afford } \\
\text { an attorney, one will } \\
\text { be appointed to } \\
\text { represent you... } \\
(7.0 \%)\end{array}$ & $\begin{array}{l}\text { If you can't get aford to buy for a lawyer } \\
\text { they may just give you any lawyer, and } \\
\text { maybe he can't help you. } \\
\text { If you don't have money to hire a lawyer } \\
\text { they will send you a free one if you say } \\
\text { yes. }\end{array}$ & $\begin{array}{l}\text { You can sign any time. } \\
\text { If you have ability to pay to it (tonight?) } \\
\text { If you cannot afford it, you can have a } \\
\text { conversation to talk about it if you want. } \\
\text { We will answer your question if you want. }\end{array}$ \\
\hline $\begin{array}{l}\text {... before any } \\
\text { questioning if you } \\
\text { wish. }(0 \%)\end{array}$ & $\mathrm{N} / \mathrm{A}$ & $\begin{array}{l}\text { You can get an appointment before you present } \\
\text { if you went. } \\
\text { You will in the prison if you can afford that. }\end{array}$ \\
\hline $\begin{array}{l}\text { You can decide at } \\
\text { any time to exercise } \\
\text { these rights and not } \\
\text { answer any questions } \\
\text { or make any } \\
\text { statements. } \\
(18.3 \%)\end{array}$ & $\begin{array}{l}\text { You can choose to use your right at any } \\
\text { time. } \\
\text { You have the right to talk or keep silent } \\
\text { anytime you want. }\end{array}$ & $\begin{array}{l}\text { You should answer. } \\
\text { You can write any time. } \\
\text { You can practice any time. } \\
\text { You can decide at any time to do exercise right. } \\
\text { You can exercise without do other things. } \\
\text { You can choose the time for exercises any time } \\
\text { you want. }\end{array}$ \\
\hline
\end{tabular}

In the case of the right to silence, the key problems stemmed from: (a) the term right, omitted by some and misheard as write or run by others; (b) the verb have, misinterpreted by some as the modal have to; and (c) the word silent, which some misheard as something and others interpreted as quiet. The basic right to have a lawyer was correctly paraphrased by $53.5 \%$ of the participants but only $10 \%$ understood that they had the right to have a lawyer present while being questioned. The confusion stemmed from: (a) the word present, interpreted as president, prison or presenter; and (b) the term questioned, omitted or reinterpreted as question.

In the case of the free attorney, only $7 \%$ understood that they could have one appointed and none displayed an understanding of the timing, before any questioning. The challenges stemmed from: (a) the term appointed, reinterpreted as the more familiar appointment, (b) represent heard as present or prison, and (c) the noun questioning, reinterpreted as the more familiar question. These misheard or reinterpreted words were then arranged in a way that made sense to the students, e.g., You can get an appointment before you present.

Last but not least, only $18.3 \%$ of the participants understood the continuity of their rights. The key obstacle to comprehension was the collocation exercise rights. In Task 2 Miranda Vocabulary Assessment, exercise was defined by L2 speakers as physical activity or practice and when the two words appeared together, they were interpreted - legitimately but incorrectly - as workout rights or rights to physical exercise.

What we saw then was consistent reliance on compensatory strategies that created plausible alternative meanings to fill the gaps created by incomplete vocabulary knowledge and weak listening skills, both involving the BLC. The resulting errors were facilitated by phonological, morphological and semantic properties of high-frequency English words:

(a) homophony and phonological similarity (right/write, present/prison/president);

(b) derivational morphology (questioned/questioning/question);

(c) polysemy (right as correct, e.g., to do exercise right; exercise as practice, e.g., You can practice any time). 
To examine whether participants were aware of their misunderstanding, we asked a subset $(\mathrm{n}=59)$ to mark their confidence in their understanding of each Miranda sentence on a rating scale of $0 \%$ to $100 \%$. We found that in $36.7 \%$ of the cases where L2 participants demonstrated no better than $50 \%$ comprehension of individual statements, they expressed a $60 \%$ or higher level of confidence. These findings suggest that participants who used linguistic resources at their disposal to construct alternative meanings had an illusion of understanding their Miranda rights.

\section{Discussion and conclusions}

The purpose of this study was to examine whether L2 speakers enrolled in advanced ESL classes had sufficient understanding to waive their Miranda rights knowingly and intelligently and to find what they actually understood when they listened to the Miranda warnings. We found that most of our L2 participants failed to understand their Miranda rights and displayed significant disadvantages in both BLC and HLC in comparison to native speakers.

When it comes to BLC, as predicted by Hulstijn (2011, 2015), both listening skills and mastery of high-frequency words were significantly worse among our L2 participants. They could process sentences with familiar content (e.g., If you don't know the answer, the teacher will help you) but did not understand the meanings of right and exercise in the context of the Miranda rights. The HLC skills - namely, the ability to process complex sentences and mastery of legal vocabulary - also turned out to be weaker among L2 speakers. Stark differences between L1 and L2 performance on Task 1 revealed that even short sentences may be misunderstood by L2 speakers if they involve unfamiliar terms, such as jury or precedent.

Such weaknesses, however, may be invisible to the untrained eye because our participants did exactly what they are expected to do, according to CEFR standards - faced with unfamiliar words, speakers at the level B1 and higher infer their meanings from context, and, faced with complicated sentences, they extrapolate their meanings, using contextual, syntactic and lexical cues (CoE, 2018: 67). Unfortunately, in the absence of basic understanding of the US criminal justice system, compensatory strategies useful in academia lead L2 speakers astray in legal contexts - the plausible alternative meanings they infer create 'an illusion of understanding'. Asked directly Do you understand? such speakers may give a confident yes and waive their useless right to talk to the President, to talk to a lawyer in prison, or to exercise in the prison yard. The discrepancies between our L2 participants' comprehension scores and confidence ratings suggest that affirmations are not a reliable indicator of understanding.

Moreover, our findings suggest that standardized assessments should not be treated as the basis for decision-making in the high-stakes context of motions to suppress, as there is no proficiency level at which L2 speakers are guaranteed to understand their rights. What needs to change is the process of communicating the rights. The Guidelines for communicating rights to non-native speakers of English (CoRG, 2015), developed by a group of international experts, articulate seven recommendations, the most important of which is that understanding should not be determined with yes/no questions, such as Do you understand? Instead, police investigators should ask suspects to restate the rights in their own words. If the suspect is unable to paraphrase the warnings in their own words, an interpreter should be called and the process repeated anew. We also see a great need for more research on police interrogation of L2 speakers. Placing SLA tools in the service of human rights, such research has great potential to assist in protecting the rights of vulnerable L2 speakers to due process and equal treatment. 


\section{References}

American Council on the Teaching of Foreign Languages (ACTFL) 2012. ACTFL Proficiency Guidelines. Retrieved on November 192018 from https://www.actfl.org/publications/guidelinesand-manuals/actfl-proficiency-guidelines-2012

Ainsworth, J. (2008) "You have the right to remain silent" but only if you ask for it just so: The role of linguistic ideology in American police interrogation law. The International Journal of Speech, Language and the Law 15/1: 1-21.

Ainsworth, J. (2010) Miranda rights: Curtailing coercion in police interrogation: the failed promise of Miranda v. Arizona. In Coulthard, M. and A. Johnson (eds.) The Routledge Handbook of Forensic Linguistics 111-125. London/New York: Routledge.

Atkins, E. and Weiss, K. (2011) Competency to waive Miranda rights. In Drogin, E., Dattilio, F., Sadoff, R. and T. Gutheil (eds.) Handbook of Forensic Assessment: Psychological and Psychiatric Perspectives 25-48. New York: John Wiley \& Sons.

Berk-Seligson, S. (2009) Coerced Confessions: the Discourse of Bilingual Police Interrogations. Berlin/New York: Mouton de Gruyter.

Blackwood, H., Rogers, R., Steadham, J. and Fiduccia, C. (2015) Investigating Miranda waiver decisions: An examination of rational consequences. International Journal of Law and Psychiatry 42/3: 11-18.

Chaulk, S., Eastwood, J. and Snook, B. (2014) Measuring and predicting police caution comprehension in adult offenders. Canadian Journal of Criminology and Criminal Justice 56/3: 323-340.

Cloud, M., Shepherd, G., Barkoff, A. and Shur, J. (2002) Words without meaning: The Constitution, confessions, and mentally retarded suspects. The University of Chicago Law Review 69/2: 495-624.

Cooper, V. and Zapf, P. (2008) Psychiatric patients' comprehension of Miranda rights. Law and Human Behavior 32: 390-405.

Communication of Rights Group (CoRG) (2015) Guidelines for Communicating Rights to Nonnative Speakers of English in Australia, England and Wales, and the USA. Retrieved on November 192018 from https://www.aaal.org/guidelines-for-communication-rights

Council of Europe (CoE) (2018) Common European Framework of Reference for Languages: Learning, Teaching, Assessment. Companion Volume with New Descriptors. Retrieved on November 192018 from https://www.coe.int/en/web/common-european-framework-referencelanguages/level-descriptions

Domanico, A., Cicchini, M. and White, L. (2012) Overcoming Miranda: A content analysis of 
the Miranda portion of the police interrogations. Idaho Law Review 49/1: 1-22.

Eades, D. (2010) Sociolinguistics and the Legal Process. Bristol, UK: Multilingual Matters.

Eades, D. (2018) Communicating the right to silence to Aboriginal suspects: Lessons from Western Australia v Gibson. Journal of Judicial Administration 28: 4-21.

Eggington, W. and Cox, T. (2013) Using elicited oral response testing to determine the need for an interpreter. Harvard Latino Law Review 16: 127-146.

Einesman, F. (2010) Cultural issues in motions to suppress statements.' In L. Friedman Ramirez, (ed.) Cultural Issues in Criminal Defense 559-628. Huntington, NY: Juris Publishing.

English, F. (2010) Non-native speakers in detention: Assessing non-native speaking detainees' English language proficiency. In Coulthard, M. and A. Johnson (eds.) The Routledge Handbook of Forensic Linguistics 423-439. London/New York: Routledge.

Feld, B. (2006) Juveniles' competence to exercise Miranda rights: An empirical study of policy and practice. Minnesota Law Review 91/1: 26-100.

Feld, B. (2013) Real interrogation: What actually happens when cops question kids? Law \& Society Review 47: 1-36.

Fenner, S., Gudjonsson, G. and Clare, I. (2002) Understanding of the current police caution (England and Wales) among suspects in police detention. Journal of Community and Applied Social Psychology 12: 83-93.

Goldstein, A. and Goldstein, N. (2010) Evaluating Capacity to Waive Miranda Rights. Oxford, UK: Oxford University Press.

Goldstein, N., Romaine, C., Zelle, H., Kalbeitzer, R., Mesiarik, C. and Wolbransky, M. (2011) Psychometric properties of the Miranda Rights Comprehension Instruments with a juvenile justice sample. Assessment 18/4: 428-441.

Goldstein, A., Zelle, H. and Grisso, T. (2012) Miranda Rights Comprehension Instruments: $M R C I$. New York: Professional Resource Press.

Grisso, T. (1981) Juveniles' Waiver of Rights: Legal and Psychological Competence. New York: Plenum.

Grisso, T. (1998) Instruments for Assessing Understanding and Appreciation of Miranda Rights. New York: Professional Resource Press.

Hulstijn, J. (2011) Language proficiency in native and nonnative speakers: An agenda for research and suggestions for second-language assessment. Language Assessment Quarterly 8/3: 229-249. 
Hulstijn, J. (2015) Language Proficiency in Native and Non-native speakers: Theory and Research. Amsterdam/Philadelphia: John Benjamins.

Innes, B. and Erlam, R. (2018) Did he understand his rights? Assessing the comprehensibility of police cautions in New Zealand. The International Journal of Speech, Language and the Law 25/1: 21-51.

Kassin, S., Leo, R., Meissner, C., Richman, K., Colwell, L., Leach, A. and La Fon, D. (2007) Police interviewing and interrogation: A self-report survey of police practices and beliefs. Law and Human Behavior 31: 381-400.

Larson-Hall, J. (2010) A Guide to Doing Statistics in Second Language Research Using SPSS. New York/London: Routledge.

Leo, R. (2008) Police Interrogation and American Justice. Cambridge, MA/London: Harvard University Press.

Lu, X. (2010) Automatic analysis of syntactic complexity in second language writing. International Journal of Corpus Linguistics 15/4: 474-496.

Michigan English Language Assessment Battery (MELAB) (2017) Linking the Common European Framework of Reference and the Michigan English Language Assessment Battery. Technical report. Retrieved on November 192018 from https://michiganassessment.org/wpcontent/uploads/2017/04/MELAB-CEFR-Linking-Technical-Report.pdf

Papageorgiou, S., Tannenbaum, R., Bridgeman, B. and Cho, Y. (2015) The association between TOEFL iBT test scores and the Common European Framework of Reference (CEFR) levels. Retrieved on November 192018 from https://www.ets.org/Media/Research/pdf/RM-1506.pdf

Pavlenko, A. (2008) "I'm very not about the law part": Non-native speakers of English and the Miranda warnings. TESOL Quarterly 42/1: 1-30.

Rock, F. (2007) Communicating Rights: The Language of Arrest and Detention. New York: Palgrave Macmillan.

Rogers, R., Correa, A., Hazelwood, L., Shuman, D., Hoersting, R. and Blackwood, H. (2009) Spanish translations of Miranda Warnings and the totality of the circumstances. Law and Human Behavior 33: 61-69.

Rogers, R. and Drogin, E. (2015) Miranda rights and wrongs: Matters of justice. Court Review 51: $150-156$.

Rogers, R., Fiduccia, C., Steadham, J., Drogin, E., Clark, J. and Cramer, R. (2013) General 
knowledge and misknowledge of Miranda rights: Are effective Miranda advisements still necessary? Psychology, Public Policy and Law 19/4: 432-442.

Rogers, R., Harrison, K., Shuman, D., Sewell, K. and Hazelwood, L. (2007a) An analysis of Miranda warnings and waivers: Comprehension and coverage. Law and Human Behavior 31: 177-192.

Rogers, R., Harrison, K., Hazelwood, L. and Sewell, K. (2007b) Knowing and intelligent: A study of Miranda warnings in mentally disordered defendants. Law and Human Behavior 31: 401-418.

Rogers, R., Hazelwood, L., Sewell, K., Harrison, K. and Shuman, D. (2008) The language of Miranda warnings in American jurisdictions: A replication and vocabulary analysis. Law and Human Behavior 32: 124-136.

Rogers, R., Rogstad, J., Gillard, N., Drogin, E., Blackwood, H. and Shuman. D. (2010) "Everyone knows their Miranda rights": Implicit assumptions and countervailing evidence. Psychology, Public Policy and Law 16/3: 300-318.

Rogers, R., Sewell, K., Drogin, E. and Fiduccia, C. (2012) Standardized Assessment of Miranda Abilities (SAMA). New York: Psychological Assessment Resources.

Scherr, K. and Madon. S. (2013) "Go ahead and sign": An experimental examination of Miranda waivers and comprehension. Law and Human Behavior 37/3: 208-218.

Shuy, R. (1997) Ten Unanswered Language Questions about Miranda. Forensic Linguistics 4/2: 175-196.

Snook, B., Eastwood, J. and McDonald. S. (2010) A descriptive analysis of how Canadian police officers administer the right-to-silence and right-to-legal-counsel cautions. Canadian Journal of Criminology and Criminal Justice 52, 5: 545-560.

US Census Bureau (2018) 2017 American Community Survey 1-year estimates. [Retrieved on November 19, 2018 from https://factfinder.census.gov/faces/tableservices/jsf/pages/productview.xhtml?pid=ACS_17_1YR _S0501\&prodType=table

Wrightsman, L. and Pitman, M. (2010) The Miranda Ruling: Its Past, Present and Future. Oxford/New York: Oxford University Press.

\section{Cases cited}

Colorado v. Spring, 479 U.S. 157 (1986).

Dickerson v. United States, 530 U.S. 428 (2000).

Miranda v. Arizona, 384 U.S. 436 (1966). 


\footnotetext{
${ }^{\mathrm{i}}$ https://nypost.com/2014/10/31/miranda-rights-and-wrongs/

${ }^{i i}$ Since Spanish is the most frequently spoken language in the USA after English, we were eager to include a Spanish-speaking group in our sample. Unfortunately, the four universities where we collected data didn't have sufficient numbers of students from Spanish-speaking countries. As a consequence, the Spanish speakers we collected data from were not directly comparable to the main sample, due to the lower levels of education. This data will form the basis of our follow-up study.

${ }^{\text {iii }}$ An additional group of 10 L1 Chinese speakers was given a Miranda quiz but since only 10 people participated in the task we will not discuss its results here.

${ }^{\text {iv }}$ Because our data are not normally distributed, we opted for nonparametric statistical tests. In the case of our tests for group differences, this involved the Kruskal-Wallis test (the nonparametric counterpart to the one-way ANOVA) to test for an overall significant difference among the three groups of participants, followed by a series of pairwise Mann-Whitney tests (the nonparametric counterpart to the independent-samples T-test) to isolate which specific pairs of groups differed significantly from each other (see Larson-Hall, 2010, pp. 373-380). The Kruskal-Wallis test produces an $\mathrm{H}$ statistic, degrees of freedom (df), and a significance (p) value. The Mann-Whitney test produces a $\mathrm{U}$ statistic as well as a p value. For our correlation tests, we chose Spearman's rho $\left(r_{s}\right)$, which is the nonparametric counterpart to Pearson's r (see Larson-Hall, 2010, pp. 159-161). Following standard practice, we adopted an alpha level of .05-identifying p values lower than .05 as significant.
} 